To cite this article: Ozer S, Ince S, Koyi TS, Cikmazkara A, Ozeren SG, Bilgi Z, Batirel HF. Sustained preservation of pulmonary function after pleurectomy/ decortication: should it be the main reason to perform surgery in malignant pleural mesothelioma patients? Curr Thorac Surg 2019;4(3):120-125.

\title{
Sustained preservation of pulmonary function after pleurectomy/ decortication: should it be the main reason to perform surgery in malignant pleural mesothelioma patients?
}

\author{
(i) Simge Ozer ${ }^{1}$, (i) Serdar Ince ${ }^{1}$, iD Tugce Sevval Koyi ${ }^{1}$, iD Aslihan Cikmazkara ${ }^{1}$, (iD Sevim Gulsen Ozeren ${ }^{1}$, \\ (iD Zeynep Bilgi², (D) Hasan Fevzi Batirel1*
}

'Department of Thoracic Surgery, Marmara University, School of Medicine, Istanbul, Turkey

${ }^{2}$ Department of Thoracic Surgery, Medeniyet University, School of Medicine, Istanbul, Turkey

\begin{abstract}
Background: Pleurectomy/decortication for malignant pleural mesothelioma is performed to improve survival and pulmonary function. Our aim was to analyze pulmonary function outcomes following pleurectomy/decortication.
\end{abstract}

Materials and Methods: 95 patients underwent pleurectomy/decortication for mesothelioma between years 2005-2016. 30 patients were alive at the time of analysis. Three patients were not fit to perform spirometry and three patients were living in rural areas. In 24 patients, spirometry was performed and compared with preoperative values. Demographic data, side, surgical technique, histology, recurrence, FEV1 ( $\%$ and L), FVC ( $\%$ and L), change in FEV1 and FVC were recorded and analyzed. A control group $(n=9)$ was formed with lung cancer patients who underwent lower lobectomy.

Results: Average age was $56 \pm 10$ years (26-75). 13 extended and 11 partial pleurectomy/decortications were performed. Average hospital stay was $6.9 \pm 3.4$ days. 21 patients had epithelioid and 13 had T3-4 tumors. 23 patients had adjuvant chemotherapy, while 7 had adjuvant high dose radiation. Median survival was 31 months (6.4 - 83). Average preoperative and recent FEV1 (L) were 2.18 \pm 0.82 and 1.84 \pm 0.61 respectively $(\mathrm{p}=0.004)$. The values were slightly higher for lower lobectomy patients. Average percentage change in FEV1 was $-11.5 \pm 23$ which was very similar with control group (-12.4 \pm 15$)$. In 6 MPM patients, recent FEV1 (L) was higher than preoperative.

Conclusions: Pleurectomy/decortication results in stable or improved pulmonary function in $40 \%$ of the patients independent of survival. The change in FEV1 is identical with lower lobectomy patients. Pleurectomy/decortication should be the preferred technique in resectable mesothelioma patients.

Key Words: malignant pleural mesothelioma, pulmonary function, pleurectomy/decortication

Corresponding Author*: Hasan F. Batirel, MD, PhD. Marmara University Hospital, Thoracic Surgery Department, 7. Kat, Gogus Cerrahisi. Fevzi Cakmak Mah., Mimar Sinan Cad., No: 41, 34899, Ust Kaynarca, Pendik, Istanbul, Turkey.

E-mail: hbatirel@marmara.edu.tr Phone: +90 5336467877

Doi: $10.26663 /$ cts. 2019.00123

Received 17.04.2019 accepted 08.07.2019

This study was presented as an e-poster at the 25th ESTS Annual Meeting in Innsbruck, 27-31 May, 2017. 


\section{Introduction}

Surgical treatment of MPM has been a controversial topic over the last two decades $[1,2]$. While the goal of the surgical treatment is often stated as macroscopic complete resection in line with general oncologic resection principles, various techniques evolved to achieve this goal. The most prominent of those techniques is extrapleural pneumonectomy (EPP) which offers the most extensive resection with curative intent, but ultimately long-term data revealed that it often results in increased mortality/morbidity, limited quality of life, inability to complete other treatment modalities and no significant improvement in survival when compared to other modalities [1-5]. EPP also requires a rigorous patient selection criterion, which excludes a large portion of patients with MPM. Pleurectomy/decortication (PD) and extended pleurectomy/decortication (EPD) on the other hand, are usually safe in a wider patient population, results in cytoreduction with lower macroscopic complete resection rates with comparable survival outcomes $[1,2,6,7]$. PD and EPD also provide a good performance status and quality of life, most likely owing to the preservation of the lung capacity and biological behavior of the mesothelioma $[8,9]$.

Since the fact that justification of surgery in MPM patients relies on preservation of performance status and retaining the ability to follow through multiple treatment modalities and removing maximal tumor burden, long-term pulmonary function data is important. The objective of this study is to analyze pulmonary function over survival time in a cohort of patients who had P/D in our institution for MPM and compare it with a control group of lung cancer patients who underwent lower lobectomy.

\section{Materials and Methods}

All patients undergoing P/D for MPM since 2005 were recorded in a prospective database. Information on patient demographics, medical history (comorbidities, previous malignancy etc.), preoperative assessment (PFT, clinical stage, tissue diagnosis etc.), operative outcomes (resection status, pathologic type and stage, complications, length of hospital stay) and postoperative outcomes (additional treatment modalities, surviv- al, follow up pulmonary function tests) were gathered.

All patients with radiologically resectable MPM and no bulky mediastinal or extrapleural lymph node metastasis were evaluated for multimodality treatment. Preoperatively, patients underwent thoracoabdominal CT scan, PET-CT, laboratory and pulmonary function tests and cardiac evaluation. Mediastinal staging was based PET-CT. If there was any suspicious mediastinal lymph node involvement, cervical mediastinoscopy was performed.

Surviving patients at the time of analysis were determined. They were called for a pulmonary function test (PFT). Preoperative and recent PFTs were compared. A control group was formed with non-small cell lung cancer (NSCLC) patients who underwent lower lobectomy through a thoracotomy. PSPP 1.0.0.0 for GNU was used for statistical analysis. Fisher's exact, Chi-Square and Students T tests were used for comparison.

\section{Technique of PD}

MPM patients who underwent PD were classified according to the recent recommended nomenclature for mesothelioma surgery techniques [10]. We typically performed the resection through a posterolateral thoracotomy. In all cases, sixth rib was removed. Complete removal of all the parietal and visceral pleura including the fissures was the aim of the surgical exploration.

\section{Results}

95 patients underwent PD between years 2005-2016. 30 patients were alive at the point of analysis. Three patients were not fit to follow up due to chemotherapy and 3 were lost to follow up. 24 patients were included in the analysis. 14 patients were found to be surviving beyond 24 months. Four patients had removal and reconstruction of the diaphragm. Average follow up time was $31 \pm 20.6(6.4-83)$ months. Characteristics of patients who underwent PD and lower lobectomy are shown in table 1 .

Average preoperative and recent FEV1 of MPM patients were $2.18 \pm 0.82$ and $1.84 \pm 0.61 \mathrm{~L}$ respectively (Figure 1).

The values in NSCLC patients were slightly higher (Figure 2). 
Table 1. Comparison of patients who underwent pleurectomy decortication and lower lobectomy.

\begin{tabular}{|c|c|c|c|}
\hline & MPM (n=24) & NSCLC (n=9) & $\begin{array}{l}\mathrm{P} \\
\text { value }\end{array}$ \\
\hline Age (years) & $56 \pm 10$ & $55 \pm 14$ & 0.94 \\
\hline Gender (M/F) & $14 / 10$ & $8 / 1$ & 0.21 \\
\hline $\begin{array}{l}\text { Type of Op- } \\
\text { eration }\end{array}$ & $\begin{array}{l}\text { Extended P/D:4 } \\
\text { Total P/D:9 } \\
\text { Partial P/D:11 }\end{array}$ & $\begin{array}{l}\text { RLL:5 } \\
\text { LLL:4 }\end{array}$ & \\
\hline Cell type & $\begin{array}{l}\text { Epitheloid:21 } \\
\text { Biphasic:3 }\end{array}$ & NA & NA \\
\hline $\begin{array}{l}\text { Macroscopic } \\
\text { complete re- } \\
\text { section }(\mathrm{Y} / \mathrm{N})\end{array}$ & $\begin{array}{l}\mathrm{Y}: 13 \\
\mathrm{~N}: 11\end{array}$ & NA & NA \\
\hline $\begin{array}{l}\text { Adjuvant } \\
\text { treatment }\end{array}$ & $\begin{array}{l}\text { Chemotherapy: } 23 \\
\text { Hemithoracic } \\
\text { irradiation: } 7\end{array}$ & NA & NA \\
\hline $\begin{array}{l}\text { Average } \\
\text { preop- } \\
\text { erative FEV1 } \\
(\text { FEV1\%) }\end{array}$ & $\begin{array}{l}2.18 \pm 0.82 \\
(77.88 \pm 21.13)\end{array}$ & $2.7 \pm 0.5(83.1 \pm 9.7)$ & 0.085 \\
\hline $\begin{array}{l}\text { Average } \\
\text { recent FEV1 } \\
(\text { FEV1\%) }\end{array}$ & $\begin{array}{l}1.84 \pm 0.61 \\
(68.33 \pm 17.95)\end{array}$ & $2.4 \pm 0.8(75.2 \pm 20.5)$ & 0.039 \\
\hline $\begin{array}{l}\text { Average \% } \\
\text { change in } \\
\text { FEV1 }\end{array}$ & $-11.5 \pm 22.7$ & $-12.4 \pm 14.9$ & 0.9 \\
\hline $\begin{array}{l}\text { Average pre- } \\
\text { operative FVC } \\
(\mathrm{FVC} \%)\end{array}$ & $\begin{array}{l}2.77 \pm 0.99 \\
(82.75 \pm 23.13)\end{array}$ & $3.5 \pm 0.6(87.5 \pm 9.7)$ & 0.036 \\
\hline $\begin{array}{l}\text { Average } \\
\text { recent } \mathrm{FVC} \\
(\mathrm{FVC} \%)\end{array}$ & $\begin{array}{l}2.29 \pm 0.7 \\
(69.33 \pm 17.78)\end{array}$ & $3.29 \pm 1.3(81 \pm 27.7)$ & 0.009 \\
\hline $\begin{array}{l}\text { Average \% } \\
\text { change in } \\
\text { FVC }\end{array}$ & $-11.4 \pm 32.3$ & $-11.9 \pm 26.1$ & 0.98 \\
\hline $\begin{array}{l}\text { Improvement } \\
\text { in PFT }(Y / N)\end{array}$ & $6 / 18$ & $3 / 6$ & 0.25 \\
\hline $\begin{array}{l}\text { Average } \\
\text { follow-up } \\
\text { (months) }\end{array}$ & $31 \pm 20.6$ & $32.8 \pm 20.6$ & 0.97 \\
\hline
\end{tabular}

Abbrev.: MPM: Malignant pleural mesothelioma, NSCLC: non-small cell lung cancer, P/D: pleurectomy/decortication, FEV1: forced expiratory volume in 1 second, FVC: forced vital capacity, PFT: pulmonary function test.

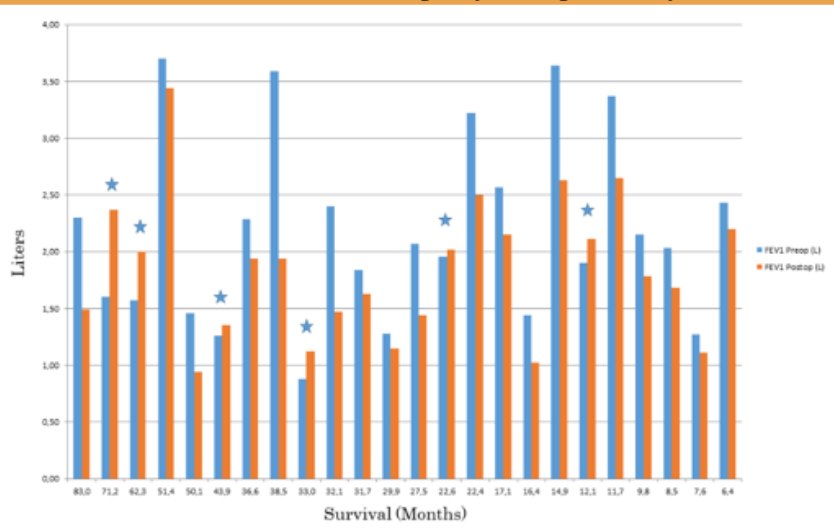

Figure 1. Measured values of FEV1 in each PD patients pre- and postoperatively. Patients with improved FEV1 are marked with a star. Four of 6 patients who had improved FEV1 were survivors beyond 2 years. In 2 additional patients the decrease in FEV1 was less than $10 \%$.

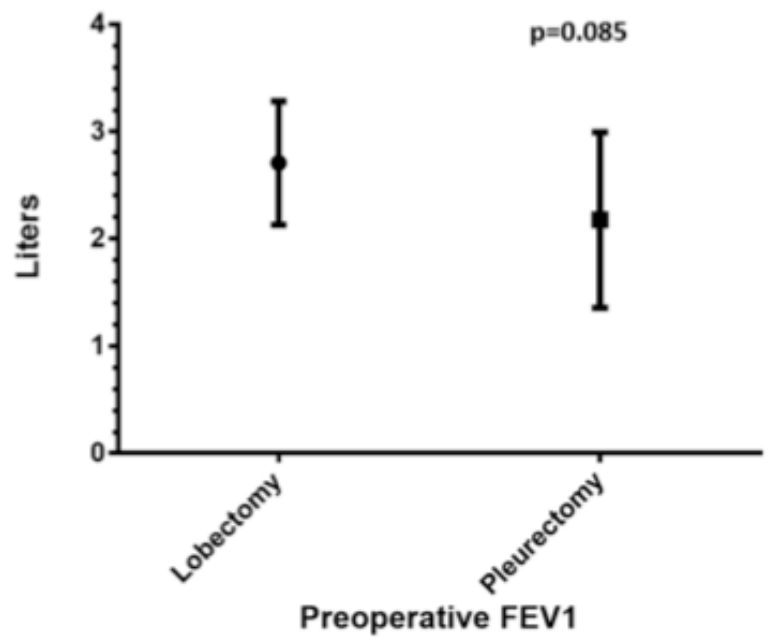

Figure 2. Preoperative FEV1 of PD $(n=24)$ and lower lobectomy $(\mathrm{n}=9)$ patients. The FEV1 values were $2.18 \pm 0.82$ and $2.71 \pm 0.58$ respectively $(\mathrm{p}=0.085)$.

Average preoperative and recent FVC of MPM patients were $2.77 \pm 0.99$ and $2.29 \pm 0.7$ respectively. Both were significantly higher in NSCLC patients. FEV1 values were found to be improved in 6 patients who had statistically significant loss of pulmonary function when compared to remaining patients $(1.53 \pm 0.41$ vs $2.39 \pm 0.81, p=0.003)$.

No statistically significant difference was observed between lobectomy and PD patients in terms change in FEV1 and FVC (Table 1). Both groups experienced almost 12 percent loss in FEV1 over similar mean follow up (Figure 3).

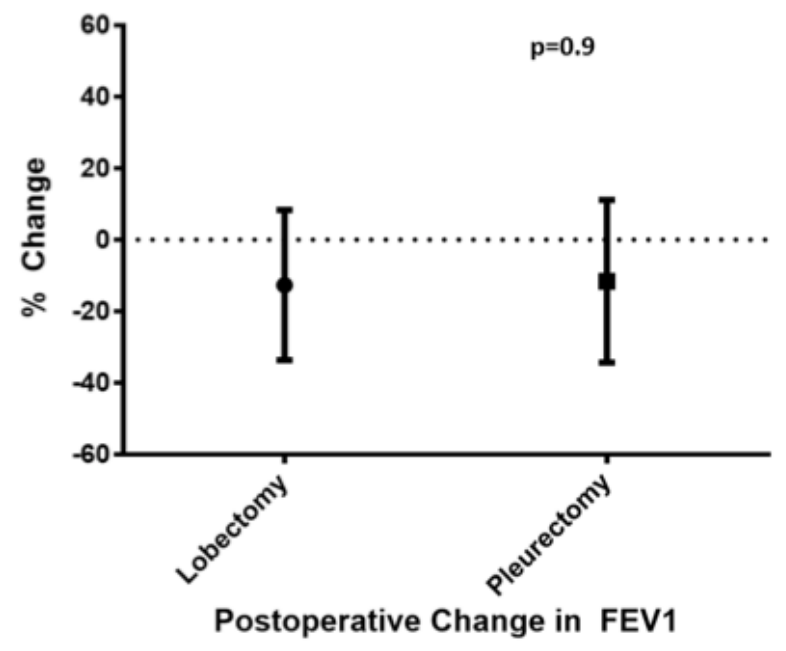

Figure 3. Change in FEV1 in PD $(n=24)$ and lower lobectomy $(\mathrm{n}=9)$ patients. Average decrease was $-11.5 \pm 22.7$ and $-12.4 \pm 14.9$ respectively $(\mathrm{p}=0.9)$. 
Presence of recurrence $(n=9)$ was associated with a higher percentage of FEV1 drop $(-18 \pm 13 \%)$ when compared with patients who did not have any recurrence $(n=15,-8 \pm 7 \%)(p=0.33)($ Figure 4$)$.

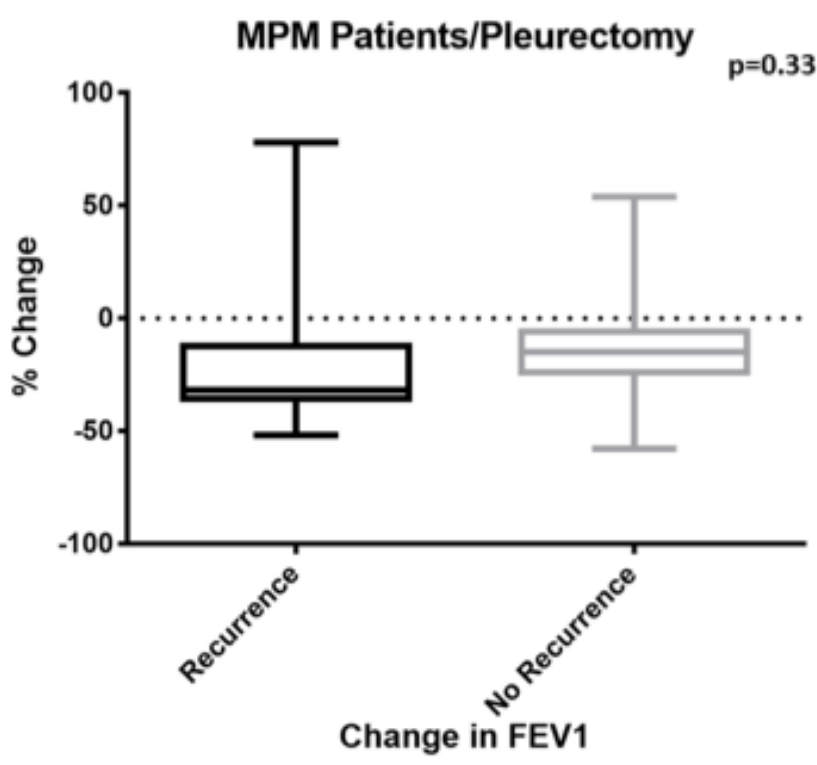

Figure 4. The decrease in FEV1 was more limited in patients without recurrence $(-8 \pm 7 \%)$. In patients with recurrence the decrease was more profound $(-18 \pm 13)$. However, the difference did not reach significance $(\mathrm{p}=0.33)$.

The difference was not also significant when two techniques were compared. Total or extended PD $(n=13)$ did not result in a better FEV1, however it can be seen in the scatter plot that it may result in better FEV1 in a larger series (Figure 5).

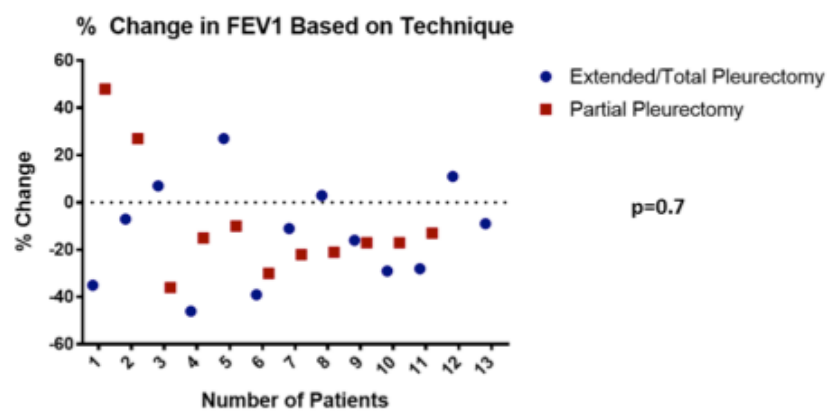

Figure 5. A total of 4 patients with EPD or PD had improved FEV1, compared with only two patients with partial PD. The difference was not significant as well $(\mathrm{p}=0.7)$.

\section{Discussion}

Surgical treatment of MPM has been a controversial topic over the last two decades. Even with the multimodality treatment protocols, MPM's prognosis remains dire with median survival just under two years and fiveyear survival is negligible [11]. Surgery's place in the multimodality treatment protocols has been hard to define due to the small patient pool, variety of techniques and definitions [12]. Moreover, the peculiar biological behavior and spread patterns of MPM renders oncologic surgery with traditional curative intent (R0 resection) technically impossible in many of the cases or it comes at the cost of excessive mortality/morbidity.

Studies focusing on survival also reflect that adoption of less aggressive surgical options sacrificing oncological "quality", even pursuing maximal cytoreduction instead of macroscopic complete resection result in comparable outcomes $[1,2]$. This concept also applies to a wide patient population, covering the patients who would be dropped as unfit (e.g.: cannot tolerate lung or diaphragm resection). Therefore, the question of how extensive MPM surgery should be remains. This question needs to be examined on two fronts. First is survival, which is comparable to larger case series despite being out of scope of this article. Second is disease specific quality of life, which can be quantified as preservation of pulmonary function in MPM patients.

In patients who underwent extrapleural pneumonectomy (EPP), following initial decrease in quality of life, a stabilization occurred at 6 months postoperatively and after 12 months, progressive deterioration in pulmonary function and quality of life was evident [13]. A study comparing changes in pulmonary function following EPP and PD, showed preservation of pulmonary function following PD, whereas a significant deterioration following EPP (14). Changes in pulmonary function following PD or EPD were analyzed in several studies and are listed in table $2[9,15,16]$. Interestingly improvement in pulmonary function and quality of life following neoadjuvant chemotherapy was associated with radiologic regression of the tumor [17]. A positive change of $7 \%$ in FEV1 and $6 \%$ in FVC were related with a radiologic partial response. 


\begin{tabular}{|c|c|c|c|c|c|}
\hline $\begin{array}{l}\text { Table 2. Stuc } \\
\text { pulmonary fu }\end{array}$ & & eratı & $\begin{array}{l}\text { focusing } \\
\text { g PD. }\end{array}$ & postop & ve \\
\hline $\begin{array}{l}\text { Authors, study } \\
\text { year }\end{array}$ & $\mathrm{n}$ & $\begin{array}{l}\text { Surgi- } \\
\text { cal } \\
\text { tech- } \\
\text { nique }\end{array}$ & $\begin{array}{l}\text { Preop- } \\
\text { erative } \\
\text { FEV1 }\end{array}$ & $\begin{array}{l}\text { Recent } \\
\text { FEV1 }\end{array}$ & $\begin{array}{l}\text { Time } \\
\text { interval } \\
\text { between } \\
\text { meas- } \\
\text { ure- } \\
\text { ments }\end{array}$ \\
\hline $\begin{array}{l}\text { Tanaka et al, } \\
2017 \text { [15] }\end{array}$ & 22 & PD & $2.35 \pm 0.59$ & $1.57 \pm 0.37$ & $\begin{array}{l}\text { Before } \\
\text { dis- } \\
\text { charge }\end{array}$ \\
\hline $\begin{array}{l}\text { Burkholder et } \\
\text { al, } 2015 \text { [16] }\end{array}$ & 36 & EPD & $74.3 *$ & $72.6 *$ & $\begin{array}{l}5-7 \mathrm{~m} \\
\text { after } \\
\text { surgery }\end{array}$ \\
\hline $\begin{array}{l}\text { Bolukbas et } \\
\text { al, } 2012 \text { [9] }\end{array}$ & 16 & EPD & $1.79 \pm 0.45$ & $2.18 \pm 0.50$ & $\begin{array}{l}2 \mathrm{~m} \\
\text { after } \\
\text { surgery }\end{array}$ \\
\hline Current study & 24 & PD & $2.18 \pm 0.82$ & $1.84 \pm 0.61$ & $\begin{array}{l}31 \pm 21 \\
\text { m. after } \\
\text { surgery }\end{array}$ \\
\hline $\begin{array}{l}\text { Abbrev.: FEV1: } \\
\text { rectomy/decortic } \\
\text { m: months } \\
* \% \text { FEV1 value } \\
\text { with performanc } \\
\text { with performanc }\end{array}$ & s. In & $\begin{array}{l}\text { d expirat } \\
\text { EPD: e. } \\
\text { this stud } \\
\text { tus } 1 \text { anc } \\
\text { us } 0 \text {. }\end{array}$ & $\begin{array}{l}\text { tory volume in } \\
\text { xtended pleur } \\
\text { ly, FEVI was } \\
d 2 \text {, whereas }\end{array}$ & $\begin{array}{l}\text { n } 1 \text { second, } \\
\text { rectomy-dec } \\
\text { improved } i \\
\text { decreased } i\end{array}$ & $\begin{array}{l}\text { PD: pleu- } \\
\text { ortication, } \\
\text { in patients } \\
\text { in patients }\end{array}$ \\
\hline
\end{tabular}

In this article, we provide pulmonary function data of long-term survivors of MPM. Prognostic factors other than oncological staging have been studied and validated by many clinics, newer markers are being established. In one report, favorable prognostic factors in $117(18 \%)$ patients who survived longer than 3 years out of 636 patients were analyzed [18]. Those patients were younger, predominantly female, more frequently had epithelioid histology and normal complete blood cell counts. Those factors were validated in other patient pools.

\section{Limitations of the Study}

First of all, it is a single institution study that includes limited number of patients treated over more than a decade. 23 out of 24 patients received chemotherapy, which may also have a role in improvement of lung function. The study includes only surviving patients, thus it does not reflect the pulmonary function outcome in patients who had early recurrence and rapid deterioration, but there are patients with limited or extensive recurrence in the patient group. Seven of the 24 PD patients passed away due to progression of MPM after this study. Despite all these limitations, this is the first study in literature that presents pulmonary function data in long-term in MPM patients.
Better preservation of lung function and decreasing actual tumor burden may also help patients to remain fit for treatment methods (chemotherapy, radiotherapy) that they could not receive otherwise. This fact has been demonstrated in our data as well with $25 \%$ of survivors still exhibiting improved lung functions and overall PFTs are in line with a control group who has undergone lower lobectomy for lung cancer and facing much better prognosis due to the nature of their disease.

Preservation of pulmonary functions independent of survival in long term survivors is an important fact for choosing maximal cytoreductive approaches (extended/ total/partial pleurectomy) over purely palliative ones (videothoracoscopic surgery and talc pleurodesis) and radical approaches on the other end of the spectrum. The goal of non-palliative surgery in MPM should be providing maximal lung expansion via debulking as the benefit of stable or improved lung function is durable over the course of survival in well selected patients.

In conclusion, good candidates for cytoreductive surgery (extended/total/partial pleurectomy) seem to enjoy durable functional benefit beyond 2 years and PFTs results seem to be in line with patients who have undergone lower lobectomy and facing a better diagnosis. Better understanding of prognostic parameters will enable us in selection of candidates for multimodality treatment methods. In the meantime, for good surgical candidates, non-palliative cytoreductive surgery may offer the best chance for long lasting acceptable pulmonary function, enabling them to complete other modalities and enjoy better prognoses.

\section{Declaration of conflicting interests}

The authors declared no conflicts of interest with respect to the authorship and/or publication of this article.

\section{Funding}

The authors received no financial support for the research and/or authorship of this article.

\section{References}

1. Batirel HF, Metintas M, Caglar HB, Ak G, Yumuk PF, Yildizeli $\mathrm{B}$, et al. Adoption of pleurectomy and decortication for malignant mesothelioma leads to similar survival as extrapleural pneumonectomy. J Thorac Cardiovasc Surg 2016; 151: 478-84. 
2. Sharkey AJ, Tenconi S, Nakas A, Waller DA. The effects of an intentional transition from extrapleural pneumonectomy to extended pleurectomy/decortication. Eur J Cardiothorac Surg 2016; 49: 1632-41.

3. Sugarbaker DJ, Flores RM, Jaklitsch MT, Richards WG, Strauss GM, Corson JM, et al. Resection margins, extrapleural nodal status, and cell type determine postoperative long-term survival in trimodality therapy of malignant pleural mesothelioma: results in 183 patients. J Thorac Cardiovasc Surg 1999; 117: 54-65.

4. Cao C, Tian D, Park J, Allan J, Pataky KA, Yan TD. A systematic review and meta-analysis of surgical treatments for malignant pleural mesothelioma. Lung Cancer 2014; 83: 240-5.

5. Burt BM, Cameron RB, Mollberg NM, Kosinski AS, Schipper $\mathrm{PH}$, Shrager JB, et al. Malignant pleural mesothelioma and the Society of Thoracic Surgeons Database: an analysis of surgical morbidity and mortality. J Thorac Cardiovasc Surg 2014; 148: 30-5.

6. Nakas A, von Meyenfeldt E, Lau K, Muller S, Waller D. Longterm survival after lung-sparing total pleurectomy for locally advanced (International Mesothelioma Interest Group Stage T3-T4) non-sarcomatoid malignant pleural mesothelioma. Eur J Cardiothorac Surg 2012; 41: 1031-6.

7. Lang-Lazdunski L, Bille A, Papa S, Marshall S, Lal R, Galeone $\mathrm{C}$, et al. Pleurectomy/decortication, hyperthermic pleural lavage with povidone-iodine, prophylactic radiotherapy, and systemic chemotherapy in patients with malignant pleural mesothelioma: A 10-year experience. J Thorac Cardiovasc Surg 2015; 149: 558-66.

8. Mollberg NM, Vigneswaran Y, Kindler HL, Warnes C, Salgia R, Husain AN, et al. Quality of life after radical pleurectomy decortication for malignant pleural mesothelioma. Ann Thorac Surg 2012; 94: 1086-92.

9. Bölükbas S, Eberlein M, Schirren J. Prospective study on functional results after lung-sparing radical pleurectomy in the management of malignant pleural mesothelioma. J Thorac Oncol 2012; 7: 900-5.

10. Rice D, Rusch V, Pass H, Asamura H, Nakano T, Edwards J, et al. Recommendations for uniform definitions of surgical techniques for malignant pleural mesothelioma: a consensus report of the international association for the study of lung cancer international staging committee and the international mesothelioma interest group. J Thorac Oncol 2011; 6: 1304-12.
11. Pass H, Giroux D, Kennedy C, Ruffini E, Cangir AK, Rice D, et al. The IASLC Mesothelioma Staging Project: Improving Staging of a Rare Disease Through International Participation. J Thorac Oncol 2016; 11: 2082-8.

12. Utley M, Fiorentino F, Treasure T. Obtaining an upper estimate of the survival benefit associated with surgery for mesothelioma. Eur J Cardiothorac Surg 2010; 38: 241-4.

13. Ambrogi V, Mineo D, Gatti A, Pompeo E, Mineo TC. Symptomatic and quality of life changes after extrapleural pneumonectomy for malignant pleural mesothelioma. J Surg Oncol 2009; 100: 199-204.

14. Ploenes T, Osei-Agyemang T, Krohn A, Waller CF, DunckerRohr V, Elze M, et al. Changes in lung function after surgery for mesothelioma. Asian Cardiovasc Thorac Ann 2013; 21: 48-55.

15. Tanaka T, Morishita S, Hashimoto M, Itani Y, Mabuchi S, Kodama N, et al. Physical function and health-related quality of life in patients undergoing surgical treatment for malignant pleural mesothelioma. Support Care Cancer 2017; 25: 2569-75.

16. Burkholder D, Hadi D, Kunnavakkam R, Kindler H, Todd K, Celauro AD, et al. Effects of extended pleurectomy and decortication on quality of life and pulmonary function in patients with malignant pleural mesothelioma. Ann Thorac Surg 2015; 99: 1775-80.

17. Marulli G, Di Chiara F, Braccioni F, Perissinotto E, Pasello G, Favaretto AG, et al. Changes in pulmonary function tests predict radiological response to chemotherapy in malignant pleural mesothelioma. Eur J Cardiothorac Surg 2013; 44: 104-10.

18. Sugarbaker DJ, Wolf AS, Chirieac LR, Godleski JJ, Tilleman TR, Jaklitsch MT, et al. Clinical and pathological features of three-year survivors of malignant pleural mesothelioma following extrapleural pneumonectomy. Eur J Cardiothorac Surg 2011; 40: 298-303. 